\title{
Influence of oak mast on feeding behaviour of red deer (Cervus elaphus $\mathrm{L}$ )
}

\author{
JF Picard 1, P Oleffe 2, B Boisaubert 2 \\ 1 INRA-Centre de Recherches Forestières, Laboratoire de Phytoécologie Forestière, \\ Champenoux, 54280 Seichamps; \\ 2 Office National de la Chasse, CNERA Cervidés-Sanglier, Place Exelmans, \\ 55000 Bar-Le-Duc, France
}

(Received 21 January 1991; accepted 3 June 1991)

\begin{abstract}
Summary - Rumen content analysis was used for assessing the autumn and winter diet of red deer in the same forest during 2 successive hunting seasons. This paper compares the results of the second season (with an abundant oak-mast) to those obtained during the first one. The main conclusions are:

- clear relationships exist between time and/or weather conditions and the diet of red deer;

- forest fruits such as wild apples, pears and acorns are very important foods for red deer in autumn; corn consumption is reduced when acorns are available;

- sedges, grasses and fallen dead leaves (most likely taken from the soil surface) are also important foods, particularly when acorns are scarce;

- rape is mostly consumed during cold and snowy periods;

- consumption of woody twigs increases dramatically when snow covers the ground.
\end{abstract}

red deer / oak-mast / rumen content / feeding behaviour

Résumé - Influence d'une glandée importante sur le comportement alimentaire du cerf (Cervus elaphus $\mathrm{L}$ ). Le régime alimentaire automnal et hivernal d'une population de Cerf élaphe présente dans une forêt du Nord-Est de la France (Hêtraie-Chênaie calcicole) a été étudié par la technique des contenus stomacaux au cours de deux saisons de chasse successives, la dernière (19841985) étant caractérisée par une glandée abondante. De la comparaison entre les deux saisons de chasse, il ressort que les conditions météorologiques et la disponibilité offerte interfèrent sur le régime alimentaire du Cerf. Dans les deux cas, on constate:

- une consommation importante de fruits charnus (pommes et poires sauvages, pourtant relativement rares dans cette forêt) et de feuilles vertes (Charme surtout, mais aussi Aubépine) jusqu'aux premières gelées;

- une utilisation des herbacées (cypéracées, graminées cultivées ou non) tout au long de l'automne et de l'hiver;

- une augmentation importante de la consommation de brindilles dès que la neige tient au sol;

- une utilisation de Colza en période de gel etou de neige, en janvier-février.

Quand les glands sont abondants (en 1984-1985), et malgré la compétition importante exercée par les autres mammifères (Chevreuil et, surtout, Sanglier), ils sont recherchés et forment la part la plus importante du régime alimentaire $(50,8 \%$ en valeur pondérale) à cette période de l'année. Ceci en-

* Correspondence and reprints 
traine une diminution de la consommation des rameaux ligneux (8,6\% pour $19,5 \%)$, des herbacées (surtout graminées : $5,7 \%$ pour $17,1 \%$ ) et des feuilles mortes $(2,5 \%$ pour $11,3 \%$ ). L'utilisation du Colza ne semble, par contre, pas avoir été modifiée.

cerf / glandée / contenu stomacal / régime alimentaire

\section{INTRODUCTION}

Stomach content analysis is a method of studying the diet of wild animals which has been used for many years, particularly for red deer, Cervus elaphus* (Jensen, 1968; Dzieciolowski, 1970; Goffin and de Crombrugghe, 1976; Mitchell et al, 1977; Gebczynska, 1980; Picard et al, 1985).

The present research was carried out: i), to establish the importance of abundant oak-mast in the diet of red deer (acorns usually occur abundantly 1 year out of 12 in northeastern France); and ii), to compare the results in the same forest with those of the previous year, when there was no oak-mast and a poor beech-mast, but when the other trophic conditions (natural and artificial food) were the same.

During both years, autumn and winter weather conditions were similar and belonged to 4 main types:

- mild and wet;

- cold and dry;

- cold and wet;

- snowy.

\section{MATERIALS AND METHODS}

\section{Materials}

As in a previous study (Picard et al, 1985), the samples were from red deer shot in the state forest of Arc en Barrois, in northeastern France.
This forest (Allain et al, 1978) displays 3 relevant characteristics:

- the dominant tree species is oak (Quercus petraea), mixed with hornbeam (Carpinus betulus) and beech (Fagus sylvatica). The main forest ( $8000 \mathrm{ha}$ ) in which the animals were shot is surrounded by 2000 ha of smaller forests and many pastures and fields (including corn, Zea mays, and rape, Brassica napus);

- the vegetation has been heavily grazed for more than 10 years due to very high populations of game animals. Estimates based on 4 annual culls are 6-9 red deer per $\mathrm{km}^{2}, 8-10$ roe deer (Capreolus capreolus L) per $\mathrm{km}^{2}$. The density of wild boar (Sus scrofa) must also be high $(\approx 300$ animals culled each year);

- red deer are shot almost every day during late autumn and winter, except when snow is too deep; regular sampling throughout the shooting period is possible.

\section{Methods}

\section{Method for collecting samples}

As soon as an animal had been shot, the rumen was opened and its contents mixed. About 11 was stored by deep freezing.

Eighty-seven rumens were collected between 21 September, 1984, and 21 February, 1985. Figure 1 shows the structure of the sample for sex and date.

\section{Method for analysing the rumen contents}

The method used has been described and discussed by Mitchell et al (1977), Maizeret (1983) and Picard et al (1985). The samples were

* Species names are cited according to Grzimek (1978) for animals and to Tutin et al (1964) for plants. 
$I$ = One rumen content

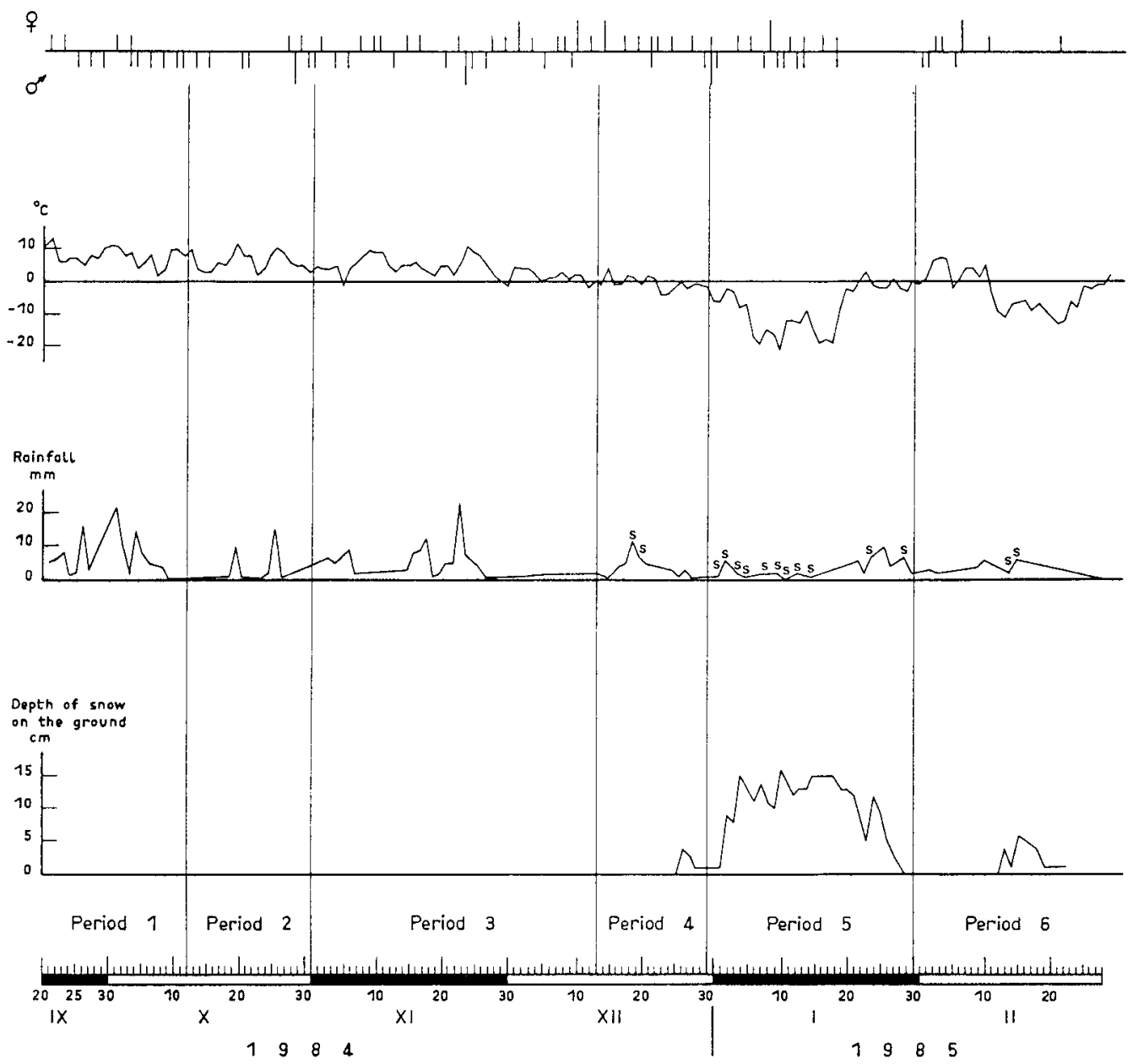

Fig 1. Distribution of rumen samples over time, minimum temperatures, rainfall and snow (S), depth of snow on the ground.

mixed after thawing, and $100 \mathrm{~g}$ were taken and sieved through 2 square mesh sieves $(5 \mathrm{~mm}$ on top and $2 \mathrm{~mm}$ beneath) under running tap water. Food fragments retained by each sieve were placed in large Petri dishes and sorted into plant groups or species using a dissecting microscope. Each specific fraction was then dried $\left(48 \mathrm{~h}\right.$ at $\left.70^{\circ} \mathrm{C}\right)$ and weighed. The result for each species was calculated as the percent dry weight of the species with respect to the total dry weight of the sample. The percentage frequency of each species was also calculated.

Use of the largest $(5 \mathrm{~mm})$ sieve permitted easier identification, but for some species the ratio "large pieces/small pieces" may be of interest, as will be demonstrated in the case of rape. 


\section{Statistical analysis}

Factorial analysis of correspondances (FAC; Lebart et al, 1984) was used to group plant species (main variables) and to relate these groups to independent variables (additional variables).

Main variables were used for the determination of axes, and additional variables were subsequently plotted on the factorial planes.
The main variables consisted of 26 categories of food items, closely related to those listed in table I.

Additional variables consisted of undetermined food items $(<0.1 \%$ of total by weight), number of each food item in a rumen, size of items, and deer weight, sex, age, length of lower jaw, date and time of death.

Six rumens containing $>50 \%$ corn were discarded because a preliminary FAC had shown

Table I. Main food items found in red deer rumens during the hunting season 1984-1985 and their percentage weight $(\% \mathrm{~W})$, frequency $(\% \mathrm{~F})$ and ranking order (RF) according to frequency.

\begin{tabular}{lrrr}
\hline Main food items & $\% W$ & $\% F$ & $R F$ \\
\hline & & & \\
Acorns & 50.8 & 56 & 8 \\
Corn (ears and grains) & 12.1 & 15 & 22 \\
Woody twigs & 8.6 & 76 & 5 \\
Apples and pears & 6.5 & 39 & 10 \\
Grasses & 5.7 & 89 & 1 \\
Rape & 4.7 & 18 & 19 \\
Leaf-stalks & 4.6 & 86 & 2 \\
Oak (dead leaves) & 1.4 & 84 & 3 \\
Sedges & 1.3 & 60 & 7 \\
Hornbeam (dead leaves) & 0.7 & 80 & 4 \\
Beech (dead leaves) & 0.4 & 72 & 6 \\
Hornbeam (green leaves) & 0.3 & 11 & 24 \\
Bramble (green leaves) & 0.3 & 45 & 9 \\
Horse-chestnuts & 0.3 & 1 & 67 \\
Hornbeam (fruits) & 0.2 & 26 & 15 \\
Crataegus sp (green leaves) & 17 & 20 \\
Aspen (Populus tremula-dead leaves) & 0.2 & 9 & 29 \\
Whitebeam (Sorbus aria-fruits) & 0.2 & 67 \\
Mosses & 0.1 & 1 & 10 \\
Pine (needles) & 0.1 & 38 & 11 \\
Ivy (Hedera helix-green leaves) & 0.1 & 5 & 14 \\
Field maple (Acer campestre-dead leaves) & 0.1 & 32 & 29 \\
Beech nuts & 0.1 & 28 & 40 \\
Various unknown fruits & 0.1 & 9 & 16 \\
Privet (Ligustrum vulgare-green leaves) & 0.1 & 6 & \\
\hline
\end{tabular}

The remainder consists of: dead leaves from trees and shrubs (Sorbus torminalis, Crataegus sp, Alnus glutinosa, Cornus sp, Corylus avellana, Fraxinus excelsior, Euonymus europaeus, Prunus avium, Ulmus minor, Pyrus communis, Malus sylvestris, Prunus spinosa, Rubus sp, Rosa sp, Salix caprea, Sorbus aucuparia, Acer pseudoplatanus, Tilia platyphyllos, Ligustrum vulgare, Viburnum lantana, Viburnum opulus), green leaves from trees and bushes (Quercus petraea, Cornus sp, Corylus avellana, Prunus avium, Pyrus communis, Malus sylvestris, Prunus spinosa, Rosa sp, Abies sp, Salix caprea, Acer pseudoplatanus, Populus tremula, Viburnum opulus), forbs (Asarum europaeum, Galium odoratum, Fragaria vesca, Hepatica nobilis, Lamiastrum galeobdolon, Glechoma hederacea, Mercurialis perennis, Hypericum hirsutum, Taraxacum sp, Potentilla sterilis, Ranunculus nemorosus, Stellaria holostea, Trifolium sp, Vicia sepium, Viola reichenbachiana) fruits (wheat, nuts, fruits from Cornus mas), fungi, male flowers from Corylus, ferns, lichens and some unknown species. 
that they occurred randomly during the hunting season and that they distorted the analysis.

\section{RESULTS}

\section{4-1985 hunting season}

Eighty-eight different food items were identified, including the dead leaves of 26 species and the green leaves of 21 species. The 25 main food items ( $>0.1 \%$ occurrence) are listed with percent weight, percent frequency and importance relative to frequency (table I).

Acorns constituted the largest component from all rumens combined $(50.8 \%)$. Only 9 food items comprised $>1 \%$, and represented $95.7 \%$ of the analysed material.

The frequency with which these various food items were found in rumens was variable and was not always related to their representation according to weight. For instance, rape and corn which were well represented in terms of weight only occurred in 18 and $15 \%$ of the rumens, respectively. Similarly, horse-chestnuts (seed from Aesculus hippocastanum), found only once, represented $0.3 \%$ of the weight of all analysed food items. Bramble leaves (Rubus $\mathrm{sp})$, on the other hand, with the same proportion in weight, were found in $45 \%$ of the rumens.

A careful examination of the first factorial graph as defined by FAC (fig 2) led to the grouping of rumens according to their contents. Six main groups corresponding to 6 distinct time periods were clearly identified:

- period 1: from 21 September to 12 October ( 13 rumens, 3 of which were from rutting animals);

- period 2: 13-31 October (10 rumens);
- period 3: from 1 November to 13 December (29 rumens, 3 of which were corndominated);

- period 4: from 14 December to $30 \mathrm{De}$ cember (11 rumens, 1 of which was corndominated);

- period 5: from 31 December, 1984, to 30 January, 1985, (50 rumens, 1 of which was corn-dominated);

- period 6: from 31 January to 21 February (9 rumens, one of which was corndominated).

Comparison with figure 1 shows that some of the limits between these periods correspond to important weather changes. More precisely, period 4 corresponds to when snow started to fall, period 5 to the presence of a constant snow layer on the ground, and period 6 to the disappearance of snow on the ground.

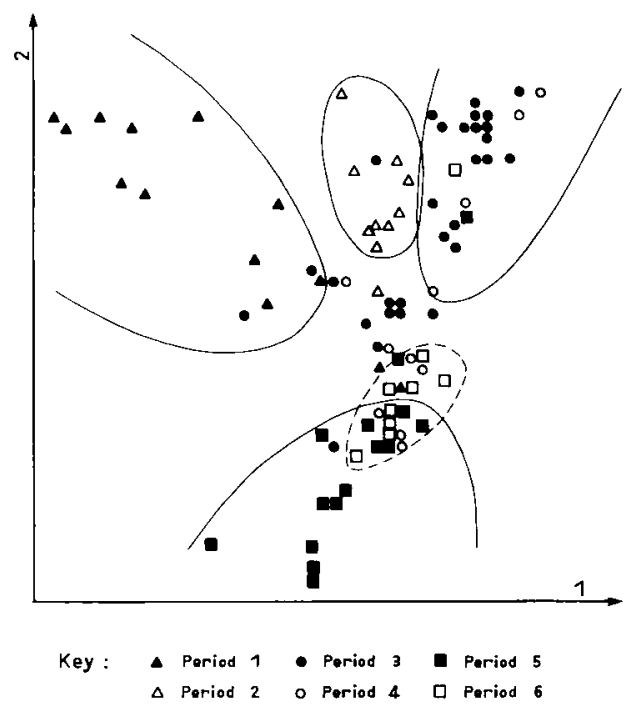

Fig 2. Factorial analysis of correspondances of the 87 rumen contents. Each point represents one rumen on the factorial graph 1-2. 
However, the 3 first periods correspond more to a change in food availability (disappearance of green leaves in autumn, rarefaction of apples and pears, appearance of acorns) than to climatic conditions.

The date on which the animals were shot was clearly related with the total number of food items in the rumen contents (including those $<0.1 \%$ of total by weight). The diet showed a wide diversity in autumn, but was much less diverse during period 5, when snow covered the ground.

FAC also showed that sex, age, time of death and other individual characteristics of the animals were not correlated with the diet. This result is consistent with those of the previous hunting season. Dzieciolowski (1970) had also found no difference between the diets of males, females and calves. However, Mitchell et al (1977) and Staines et al (1982), found differences in diet between stags and hinds.

The proportion of the different food items on a weight basis in the 6 periods defined by $F A C$ is given figure 3 .

The diet during period 1 was characterized by the abundance of pears, apples and green leaves. Some leaf-stalks and woody twigs were present, as well as grasses, sedges and corn. Some animals had already found acorns (acorns started to fall to the ground from late September, becoming abundant by mid-October).

The diet during period 2 was intermediate between those of periods 1 and 3 : acorns were already dominant. Some apples and pears were still present, but green leaves had almost completely disappeared in the rumens (they were not available any more because of leaf-fall), and dead leaves appeared. Woody twigs and leaf-stalks had decreased slightly, and grasses and sedges became very rare.

The diet during period 3 was largely dominated by acorns ( $84 \%$ of total weight).
Except for grasses $(5.1 \%)$, all other food items were decreasing.

During period 4 (first snow fall), rape appeared significantly in the rumens $(9 \%$ of total weight). Grasses, and sedges to a lesser extent, reached a maximum during the fourth period while acorns remained the basic food item ( $52.1 \%$ of total weight). Woody twigs, dead leaves and leaf-stalks had increased since the previous period.

A dramatic change occurred during period 5 when snow was covering the ground: woody twigs represented $56 \%$ (of total weight) of the rumen contents; dead leaves and grasses reached a minimum; rape was well represented in the rumens (26.3\% of total weight) despite its poor accessibility under the snow.

Period 6, which corresponded to snow thawing, seems to be intermediate between the 2 previous periods. The proportion of acorns increased again, and partly replaced woody twigs. Rape was stable and grasses increased. The rumen contents were much more varied during period 6 than during the previous ones. In 8 rumens out of 9 , different food items represented $>50 \%$ (by weight) of their total content: woody twigs for 2 rumens; acorns for 1 rumen; rape for 2 rumens; grasses for 2 rumens; corn for 1 rumen.

Thus an average diet cannot be described for this last period: it would be possible with a largest sample. The animals had difficulties in recovering a regular diet and displayed a typical opportunistic behaviour when confronted with less diverse and less available foods than at the beginning of the hunting season.

\section{Reminder of 1983-1984 hunting season}

This hunting season was divided into 4 main periods based on weather conditions (table II): 


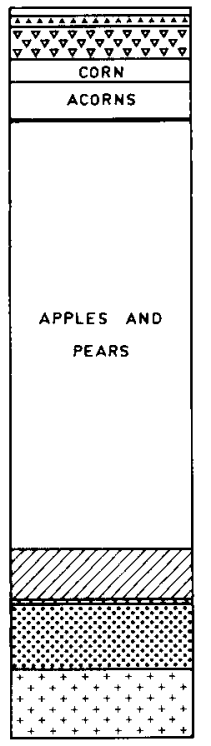

Period 1

$21 \mathrm{x}-12 \mathrm{x}$

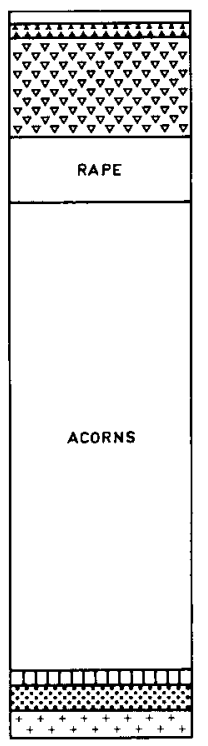

Period 4

$15 \times 11 \rightarrow 30 \times 11$

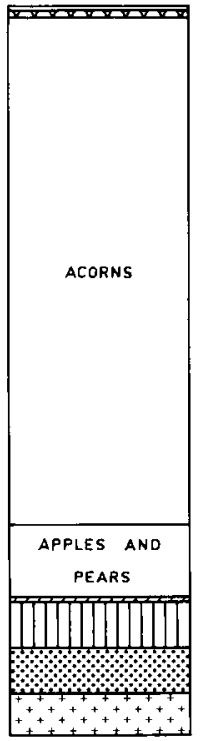

Period 2

$13 x \rightarrow 31 x$

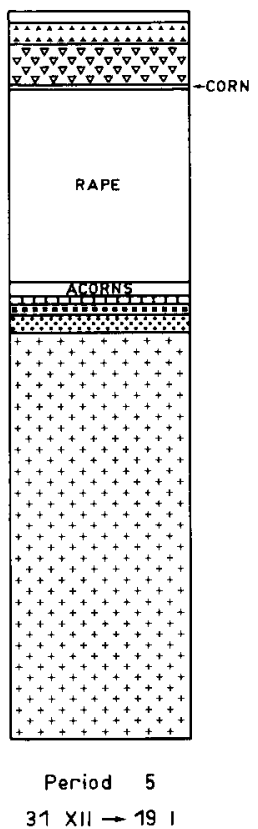

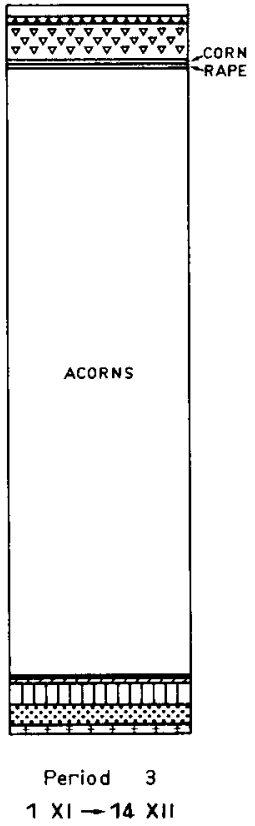

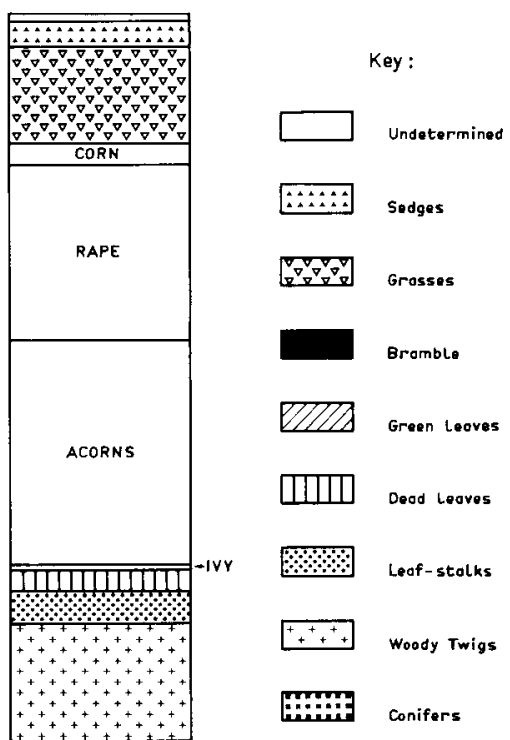

Period 6

$201-21 \|$

Fig 3. Diet of red deer (percent of different main food items, on a weight basis) during different periods of the hunting season. 
Table Il. Hunting season 1983-1984; main food items (percent) for the 4 periods.

\begin{tabular}{lcccc}
\hline Food item & $\begin{array}{c}\text { 1st period } \\
\text { (Before 10/21) }\end{array}$ & $\begin{array}{c}\text { 2nd period } \\
(10 / 21-12 / 17)\end{array}$ & $\begin{array}{c}\text { 3rd period } \\
(12 / 17-01 / 20)\end{array}$ & $\begin{array}{c}\text { 4th period } \\
\text { (After 01/20) }\end{array}$ \\
\hline Miscellaneous & 1.6 & 1.0 & 1.7 & 2.0 \\
Sedges & 2.9 & 7.0 & 14.3 & 7.7 \\
Grasses & 8.3 & 17.6 & 28.7 & 24.7 \\
Corn & - & 14.4 & 0.5 & - \\
Rape & - & 0.1 & 0.1 & 3.9 \\
Beech nuts & 1.4 & 10.5 & 11.2 & 0.1 \\
Pears and apples & 14.1 & 1.0 & 0.1 & 0.1 \\
Mushrooms & 0.6 & 0.8 & 0.5 & 0.4 \\
lvy & 2.8 & 2.3 & 0.6 & 3.4 \\
Bramble & 1.3 & 1.5 & 0.3 & 0.2 \\
Green leaves & 11.8 & 1.6 & 0.2 & 0.1 \\
Dead leaves & 17.3 & 18.1 & 13.4 & 0.2 \\
Leaf-stalks & 19.6 & 11.5 & 10.6 & 10.8 \\
Woody twigs & 18.3 & 12.6 & 17.8 & 46.4 \\
\hline
\end{tabular}

- before October 20: weather mild and wet. Deer fed mostly on green leaves of woody plants (mostly hornbeam; Carpinus betulus L and oak, Quercus sp), wild apples and pears, dead leaves and some grasses (including sedges and rushes);

- October 20-December 17: weather cold and dry. Deer fed on beech nuts and corn (from nearby fields) in addition to dead leaves and grasses in a larger amount than previously;

- December 17-January 20: weather cold and wet; dead leaves and beech nuts were still present in rumen contents, but grasses were dominant;

- after January 20: snow on the ground; no more dead leaves or beech nuts in rumen contents, slight reduction of grasses, a dramatic increase of twigs and buds from woody plants and rape leaves (Brassica napus $L$ ) from nearby fields.

\section{DISCUSSION}

\section{Comparison between years (table III)}

Acorns are seldom cited as an important food item red deer, probably because acorns (and, perhaps, oaks) are rare in the forests where most studies take place. However, Gebczynska (1980) also found an occasional high consumption of acorns, and considered that red deer fed mostly on trees and shrubs rather than on herbs and grasses. Our results do not support this view.

In the case of roe deer, Maillard (1984) also found a high consumption of acorns, reaching $87 \%$ (by weight) of the rumen contents. Jackson (1977, 1980), Fichant (1974), and Harlow et al (1975) showed that acorns were very important in autumn 
Table IIl. Ranking of the main food items (by weight, percent) for the 2 successive hunting seasons (1983-1984 and 1984-1985).

\begin{tabular}{lrlr}
\hline \multicolumn{1}{c}{$\begin{array}{c}\text { Hunting season } \\
\text { (1983-1984) }\end{array}$} & \multicolumn{1}{c}{$\begin{array}{c}\text { Hunting season } \\
\text { (1984-1985) }\end{array}$} \\
\hline Woody twigs & 19.5 & Acorns & 50.8 \\
Grasses & 17.1 & Corn & 12.0 \\
Leaf-stalks & 12.5 & Woody twigs & 8.6 \\
Corn & 12.2 & Grasses & 5.7 \\
Beechnuts & 8.7 & Rape & 4.7 \\
Oak, dead leaves & 8.4 & Leaf-stalks & 4.6 \\
Sedges & 6.2 & Wild apples & 2.4 \\
Hornbeam, dead leaves & 2.1 & Wild pears & 2.3 \\
Wild apples & 2.1 & Oak, dead leaves & 1.4 \\
Hornbeam, green leaves & 1.6 & Sedges & 1.3 \\
Wild pears & 1.3 & Hornbeam, dead leaves & 0.7 \\
Beech, dead leaves & 1.2 & Beech, dead leaves & 0.4 \\
Rape & 1.0 & Hornbeam, green leaves & 0.3 \\
Bramble, green leaves & 0.5 & Brambles, green leaves & 0.3 \\
& & & \\
\hline
\end{tabular}

for roe deer, fallow deer and white-tailed deer. Thus, it is clear that acorns may be an important part of the diet of deer when oak-mast is abundant.

Some other food items, such as corn, woody twigs, rape, grasses, dead leaves, ivy and bramble merit further discussion:

Corn. Important differences in corn consumption are clearly indicated between the 2 hunting seasons. During the first year, corn was found in rumens mostly between 20 October and 17 December, probably because the animals were eating the leftovers from the harvest. This was confirmed by the high frequency $(73 \%)$ of rumens with corn containing fragments of ears. In contrast, during the second year, corn was found in rumens during the whole hunting season, and only $38 \%$ of those rumens with corn contained ear fragments. It is likely that the tendency to eat corn in the fields was diverted by the abundance of acorns, which kept the red deer in the for- est for longer than usual. This hypothesis is supported by the fact that wheat was found to be mixed with corn in 2 rumens (12 January and 6 February).

Woody twigs. The mean percent of wood (by weight) in rumens differs markedly between the 2 years. Before snow and with no acorns (first year), the proportion was $15.7 \%$; with acorns (second year), it was only $6.7 \%$ before snow. However, during snowy periods, the proportion was $45.2 \%$ for the first year and $47.9 \%$ for the second one. These latter 2 proportions are quite similar and much higher than those for the period before snow: it shows that snow is a determinant in the choice of this type of food which is available above ground. This is consistent with the results of Delaunay (1983) for chamois in the French Alps.

Rape. Rumen content analysis do not lead to a correct estimation of the importance of rape in the diet of red deer during winter. This particular food item quickly disap- 
pears from the rumen, as shown by 2 observations:

- in vitro digestibility tests (Oleffe et al, unpublished observations) have shown that rape is quickly digested, even more quickly than alfalfa;

- figure 4 shows that each time rape represents $>20 \%$ (by weight) of the rumen content, most of it is in the coarse fraction (>5 mm; whole leaves or stalks or ribs). Thus, the leaf blades are quickly digested.

Another observation suggests that rape is rapidly digested: for most of animals whose rumens contained rape, shooting time was before midday and it is known that deer feed in fields exclusively by night.

However, it is probably not by chance that a large amount of rape was found for both years in the rumens after the first snow; this food item is likely to be more important for the animals when such weather conditions are prevailing. Ahlèn (1965) found that rape consumption by red deer in Scandinavia began in October and

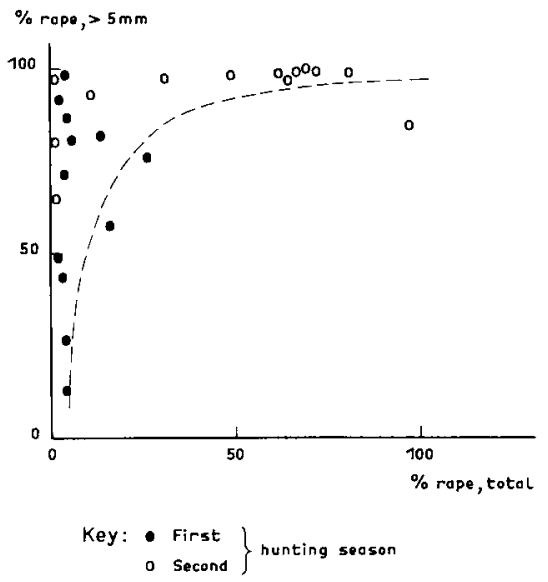

Fig 4. Percent (by weight) of rape in the coarse fraction of rumen contents (>5 mm) plotted against the percent of total rape (including smaller fractions). was very important in mid-winter, especially of plants $10-20 \mathrm{~cm}$ high.

Grasses. The results are consistent between the 2 years. After the shrubs have shed their leaves and the fleshy fruits have became scarce, grasses and sedges are a basic food for red deer. The relative importance of these food items is reduced in the case of abundant oak-mast, but they remain more represented than dead leaves which are less digestible (Oleffe, 1986), and probably overestimated by the technique used. Staines and Welch (1984) and Jensen (1968) have confirmed the importance of grasses in the diet of red deer in summer and winter.

Dead leaves. This food item was the most reduced by the presence of acorns (from $16.5 \%$ to $7 \%$ of the rumen contents by weight). The only period of the second year (with acorns) when deer ate a significant amount of dead leaves was when apples and pears became scarce and acorns were just beginning to fall.

The fact that for both years the consumption of dead leaves is negligible when snow covers the forest floor suggests that deer prefer dead leaves on the ground than those still attached to shrubs.

Ivy and bramble. Scarcity of these 2 species in the forest is probably the main reason why they are almost absent in rumens. In a nearby forest, much richer in ivy and bramble, these species sometimes represented $>50 \%$ of the rumen contents.

For the first year (Picard et al, 1985), diet was clearly related to weather. This was not the case for the second year as long as acorns were easily available on the ground. When this was the case, animals fed mostly on them after an initial period when green leaves and fleshy fruits were abundant. The slight weather changes which occurred during that period had no effect on diet. 
The first important diet modification during the second year was caused by snow, which dramatically reduced the importance of acorns. It is also probable that at the same time the stock of acorns was already significantly depleted by the earlier massive intakes, including intakes by wild boar. At the same time, grasses and sedges increased in the diet.

\section{Methodology}

This study also suggests some criticisms of the method:

- measuring the dry weight of the different food items over-represents dry fruits compared to fleshy fruits or fungi (Picard et al, 1985; Maillard and Picard, 1987). Measuring volumes (Jackson, 1977; Kay and Staines, 1981) is likely to give more reliable results as far as satiety is concerned.

- the frequency of food items recorded may give biased estimates of their importance to the animal diet due to differential digestibility: digestibility is not the same for different food items, and the time they have been in the rumen is unknown. This may introduce a bias in the interpretation of the results of rumen analysis in terms of the actual food uptake by the animals. Mclnnis et al (1983) compared 4 methods for studying the diet of sheep (direct observation, oesophageal fistulation, rumen analysis and faecal analysis) and concluded that the results of rumen analysis gave a correct estimation of the diet. However, they noted that grasses were overestimated if compared to more digestible forbs.

In spite of these criticisms, the rumen analysis method is very valuable as a complement to browsing studies, because the intake of many food items does not leave clear evidence in the forest. This is particularly true for acorns and dead leaves, the importance of which in the diet of red deer has been demonstrated in this study.

Jackson (1977) summarized the limitation of the method: "Thus quantitative comparisons between different foods only approximate indications of their relative importance (Dzieciolowski, 1970); but as Jensen (1968) indicates, when comparing the diets of large mammals it is generally of little consequence whether a food forms precisely 30,35 or $40 \%$ of the intake. The crucial point is that is forms about one third ot the diet and it is therefore a major food".

\section{CONCLUSIONS}

This study confirms the major importance of forest fruits in the autumn diet of red deer already reported (Picard et al, 1985): beech nuts and acorns (when available), and apples and pears (in spite of the rarity of fruit trees in this forest). Corn is avidly sought for by animals, in the forest on feeding places for wild boar as well as in the surrounding fields.

It is confirmed that grasses and sedges are a basic food item for red deer. However, they are temporarily neglected as long as acorns are available in large quantities. This preference for acorns is also reported by Jackson (1977) for fallow deer.

Dead leaves are also important in the diet of red deer. Jackson (1977) noted up to $59 \%$ of dead leaves in fallow deer rumens, but there have been few reports for red deer.

Bark has never been found in the rumens during the 2 years of the study. This is contrary to the results of Dzieciolowski (1970), Borowski and Kossak (1975) in Poland or of Ahlèn (1965) in Scandinavia, who consider that bark in a normal food item for red deer. 
The main difference between the 2 hunting seasons is the abundance of oakmast during the second one. The acorns were largely consumed by red deer. When acorns are available, weather (temperature and rainfall) has no significant effect on the diet except when snow covers the ground.

Nevertheless, with the exception of the last period (after 31 January) during which the diet was disturbed (and the sample too small), the results of the 2 years are consistent: according to weather conditions and food availability, red deer are able to adapt to the changing resources.

\section{ACKNOWLEDGMENTS}

The authors are grateful to the Office National des Forêts which supported this work and contributed to it by sampling the rumens and to $J$ Garbaye who helped us write the English version of this paper.

\section{REFERENCES}

Ahlèn I (1965) Studies on the red deer, Cervus elaphus $\mathrm{L}$ in Scandinavia. III. Ecological investigations. Viltrevy 3 (3), 177-376

Allain R, Commeau A, Picard JF (1978) Étude des relations forêt-cervidés en forêt domaniale d'Arc en Barrois (52). Rev For Fr 30 (5), 333-352

Borowski S, Kossak S (1975) The food habits of deer in the Bialowieza primeval forest. Acta Theriol 20 (32), 463-506

Delaunay G (1983) Suivi du régime alimentaire hivernal du chamois Rupicapra rupicapra $\mathrm{L}$ dans le parc national des Ecrins. Actes Coll Natl Mammal (Grenoble) 75-82

Dzieciolowski R (1970) Foods of the red deer as determined by rumen content analyses. Acta Theriol 15 (6), 89-110

Fichant R (1974) L'alimentation du chevreuil (Capreolus capreolus $\mathrm{L}$ ) en période automnale, dans le sud de l'Ardenne Belge, par l'analyse des contenus stomacaux. Fond Univ Luxemb Sér Notes Rech 23 pp

Gebczynska Z (1980) Food of the roe deer and red deer in the Bialowieza primeval forest. Acta Theriol 25 (40), 487-500

Goffin RA, de Crombrugghe SA (1976) Régime alimentaire du cerf (Cervus elaphus $L$ ) et du chevreuil (Capreolus capreolus $L$ ) et critères de capacité stationnelle de leurs habitats. Mammalia 40 (3), 355-376

Grzimek B (1978) Le Monde Animal en Treize Volumes. Encyclopédie de la Vie des Bêtes. Stauffacher SA, Zurich

Harlow RF, Whelan JB, Crawford HS, Skeen JE (1975) Deer foods during years of oak mast abundance and scarcity. $J$ Wild Manage 39 (2), 330-336

Henry BAM (1978) Diet of roe deer in an English conifer forest. J Wild Manage 42 (4), 937940

Jackson $J$ (1977) The annual diet of the fallow deer (Dama dama) in the New Forest, Hampshire, as determined by rumen content analysis. J Zool (Lond) 181, 465-473

Jackson J (1980) The annual diet of the roe deer (Capreolus capreolus) in the New Forest, Hampshire, as determined by rumen content analysis. J Zool (Lond) 192, 71-83

Jensen PV (1968) Food selection of the Danish red deer (Cervus elaphus $L$ ) as determined by examination of the rumen content. Dan Rev Game Biol 5 (3), 1-44

Kay RNB, Staines BW (1981) The nutrition of the red deer (Cervus elaphus). Commonw Bur Anim Nutr Ser B 51 (9), 601-622

Lebart L, Morineau A, Warwick KM (1984) Multivariate Descriptive Statistical Analysis. J Wiley and Sons, NY

Mclnnis ML, Vaura M, Krueger WC (1983) A comparison of four methods used to determine the diet of large herbivores. $J$ Range Manage 36 (3), 302-306

Maillard D (1984) Contribution à l'étude de l'alimentation automnale et hivernale du chevreuil en forêt de Haye (54) par l'analyse des contenus stomacaux. DEA, biologie et physiologie végétale, Univ Nancy I, 88 pp + annexes

Maillard D, Picard JF (1987) Le régime alimentaire automnal et hivernal du chevreuil $(\mathrm{Ca}-$ 
preolus capreolus L) dans une hêtraie calcicole déterminé par l'analyse des contenus stomacaux. Gibier Faune Sauvage 4, 1-30

Maizeret C (1983) Comportement alimentaire du chevreuil des Landes de Gascogne. Thèse, doctorat de $3^{e}$ cycle, Univ Bordeaux I, 152 pp

Mitchell B, Staines BW, Welch D (1977) Ecology of Red Deer. Institute of Terrestrial Ecology, Cambridge, $74 \mathrm{pp}$

Oleffe P (1986) Étude et prédiction de la digestibilité d'aliments forestiers chez le cerf, le chevreuil et le mouton au moyen d'une technique de fermentation in vitro. DES sciences, Univ Nancy 1, $41 \mathrm{pp}+$ annexes

Picard JF, Oleffe P, Caburet A (1985) Étude du régime alimentaire automnal et hivernal du cerf (Cervus elaphus L) et du chevreuil ( $\mathrm{Ca}$ preolus capreolus L) par l'analyse des contenus stomacaux. 17 Congr IUGB, Brussels, Sept 17-21, 439-446

Staines BW, Crisp JM, Parish T (1982) Differences in the quality of food eaten by red deer (Cervus elaphus) stags and hinds in winter. $\checkmark$ Appl Ecol 19, 65-77

Staines BW, Welch D (1984) Habitat selection of red (Cervus elaphus L) and roe (Capreolus capreolus L) deer in a Sitka spruce plantation. Proc $R$ Soc Edinb Sect $B$ (Biol) 82, 303319

Tutin TG, Heywood VH, Burges NA, Moore DM, Valentine DH, Walters SM, Webb DA (19641980) Flora Europaea. Cambridge University Press 